\title{
Potato Peels and Mixed Grasses as Raw Materials for Biofuel Production
}

\author{
Shaaban Z. Omar ${ }^{1}$, Ayad H. Hasan ${ }^{1}$ and Ivo Lalov ${ }^{2}$ \\ ${ }^{1}$ Department of Medical Microbiology, Faculty of Science and Health, Koya University, \\ Daniel Mitterrand Boulevard, Koya KOY45, Kurdistan Region - F.R. Iraq \\ ${ }^{2}$ Department of Biotechnology, Faculty of Chemical System Engineering, University \\ of Chemical Technology and Metallurgy, 8 Kliment Ohridski Blvd, 1756, Sofia, Bulgaria
}

\begin{abstract}
Biogas and fuel ethanol are renewable energy sources, can be produced from complex organic materials that are decomposed by microorganisms in the anaerobic digestion method. Potato peels (PPs) and mixed Lolium perenne and Dactylis glomerata grasses were assessed as a potential substrate for biomethanation in a batch method under mesophilic condition $\left(35^{\circ} \mathrm{C}\right)$ and ethanol fermentation. The first approach of this work was focused on pretreatment of PPs using acidic and enzymatic hydrolysis to produce biogas and ethanol fermentation using Saccharomyces cerevisiae and Safbrew $S$-33. These experiments proved that enzymatic hydrolysis produced $1.2 \mathrm{~g} / \mathrm{L}$ of ethanol involved $115 \mathrm{~h}$ of fermentation and $665 \mathrm{ml} / \mathrm{h}$ of biogas after $451 \mathrm{~h}$ of biomethanation, this was more than the outcomes of acidic treatment. The second approach was concentrated on ability of biogas and ethanol production from mixed grasses treated with different acid concentrations that produced $0.16 \mathrm{~g} / \mathrm{L}$ ethanol over 8 days of fermentation and $500 \mathrm{ml} / \mathrm{h}$ of biogas after 13 days of methanation technique. In general, the results pointed out that PPs and combined grasses can be used as potential substrates with raw materials for biogas and ethanol production.
\end{abstract}

Index Terms-Acid hydrolysis, Biogas, Biomethanation, Enzymatic hydrolysis.

\section{INTRODUCTION}

Biogases present alternative renewable energy and also decrease the dependence on fossil fuel sources (Aziz, et al., 2019). The conversion of complicated organic compounds to biogas is possible due to the cooperated role of many groups of microorganisms inducing hydrolysis, acidogenesis, acetogenesis, and methanogenesis steps (Mulat, et al., 2018). Bioethanol production from lignocellulosic biomass comprises different steps of pretreatment, hydrolysis, fermentation, and ethanol recovery (Tran, et al., 2019). Pretreatment is a significant step to modify some structural

ARO-The Scientific Journal of Koya University

Vol. VIII, No.1 (2020), Article ID: ARO.10568, 7 pages

DOI: $10.14500 /$ aro. 10568

Received 02 October 2019; Accepted 18 February 2020

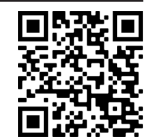

Regular research paper: Published 15 March 2020

Corresponding author's e-mail: ayad.hasan@koyauniversity.org

Copyright (C) 2020 Shaaban Z. Omar, Ayad H. Hasan and Ivo

Lalov. This is an open access article distributed under the Creative

Commons Attribution License. components of biomass that inducing glucan and xylan accessibility for additional hydrolysis processes (Thangavelu, et al., 2016). Lignocellulosic biomass is the most plentiful feedstock with seasonal availability of over 220 billion dry metric ton. Such feedstocks can be cultivated in different environments and utilized to produce renewable energy with the great potential to sequester greenhouse gases, mainly $\mathrm{CO}_{2}$ from the atmosphere (Phuttaro, et al., 2019). One source of lignocellulosic is grasses despite its rigid structure can be counted as a potential feedstock for biogas generation, due to its low water content and served as counter to other crops, and the fact that it can be grown in non-arable areas (Rodriguez, et al., 2017; Wagner, et al., 2018). Therefore, various methods based on the biodegradation and solubilization of lignin and hemicellulose have been developed to support efficient hydrolysis and promote optimal biogas production from grasses ( $\mathrm{Li}$, et al., 2012). On the other hand, waste of potato industry could be an economical carbon source for ethanol fermentation industry, this is due to their high contents of starch, cellulose, hemicellulose, lignin, and fermentable sugars to guarantee use as an ethanol feedstock (Izmirlioglu and Demirci, 2012). Potato peels (PPs) can be degraded by subsequential enzymatic hydrolysis and fermentation utilizing Saccharomyces cerevisiae to produce ethanol (Liang and McDonald, 2014).

This work aims to investigate renewable biogas and ethanol sources through the biological route of biomethanation process and ethanol fermentation using various biomass wastes (PPs and mixed grass), to analyze and determine the chemical composition of PPs and fresh mixed Lolium perenne and Dactylis glomerata grasses, and to investigate different strategies of chosen biomass substrate pre-treatment.

\section{MATERIALS AND METHODS}

\section{A. Activated Sludge (Methanogenic Consortium)}

The activated sludge used as a standard inoculum in our experiments was supplied from methanogenic reactor for the treatment of water from bioethanol production at the ALMAGEST AD, 2063 Verinsko village Ichtiman municipality, Bulgaria. 


\section{B. Substrate Preparation}

PPs

Potatoes were obtained from local market and manually peeled. Then, peels were crushed in a blender, to this $120 \mathrm{ml}$ of D.W was added for better homogenization. The liquefied substrate was stored at $4^{\circ} \mathrm{C}$ (Sanchez and Cardona, 2008).

Grasses

Fresh, perennial ryegrass (L. perenne) and cocksfoot (D. glomerata) were harvested in the beginning of June 2018 at Studentski grad park, near UCTM University campus in Sofia, fresh grass was first cut to small pieces, then $10 \mathrm{~g}$ was weighed to evaluate the dry weight by oven drying at $105^{\circ} \mathrm{C}$ for $45 \mathrm{~min}$ to a constant weight (Sanchez and Cardona, 2008).

\section{Microelements (S3 and S4)}

S3: $19.62 \mathrm{mg}$ of $\left(\mathrm{NH}_{4}\right)_{2} \mathrm{HPO}_{4}$ dissolved in $100 \mathrm{ml}$ of D.W.

$\mathrm{S} 4$ : To prepare $100 \mathrm{ml}$ of $\mathrm{S} 4$, each of the following salts was dissolved in $100 \mathrm{ml}$ of D.W. $\mathrm{MnSO}_{4} \cdot \mathrm{H}_{2} \mathrm{O}$ (4.29 mg), $\mathrm{H}_{3} \mathrm{BO}_{3}(1.34 \mathrm{mg}), \quad \mathrm{NH}_{4} \mathrm{Cl}(104.63 \mathrm{mg}), \mathrm{CaCl}_{2} . \quad 2 \mathrm{H}_{2} \mathrm{O}$ (63.67 mg), $\mathrm{ZnCl}_{2}(0.57 \mathrm{mg}), \mathrm{CoCl}_{2} \cdot 6 \mathrm{H}_{2} \mathrm{O}(7.10 \mathrm{mg}), \mathrm{KCl}$ (344.14 mg), $\mathrm{CuCl}_{2} .2 \mathrm{H}_{2} \mathrm{O}$ (0.63 mg), $\mathrm{NaMo}_{4} .2 \mathrm{H}_{2} \mathrm{O}$ (0.69 mg), and $\mathrm{MgCl}_{2} \cdot 6 \mathrm{H}_{2} \mathrm{O}(376.00 \mathrm{mg})$.

\section{Pre-treatment of Substrates}

Acid hydrolysis of PPS

Acid hydrolysis of PPs was conducted using two different sources of acidity, which were $0.5 \mathrm{M} \mathrm{HCl}$ and $1 \% \mathrm{H}_{3} \mathrm{PO}_{4}$. $\mathrm{HCl}$ hydrolysis was performed by digesting $40 \mathrm{~g}$ of PPs with $120 \mathrm{ml}$ of $0.5 \mathrm{M} \mathrm{HCl}$, the mixture was autoclaved $\left(121^{\circ} \mathrm{C}\right.$ and $1 \mathrm{~atm}$ for $15 \mathrm{~min})$. In the case of $\mathrm{H}_{3} \mathrm{PO}_{4}$ hydrolysis, two various methods were carried out. The first pre-treatment was as follows: $30 \mathrm{~g}$ of PPs were digested with $120 \mathrm{ml}$ of $1 \% \mathrm{H}_{3} \mathrm{PO}_{4}$. The resulted liquid was heated at $100^{\circ} \mathrm{C}$ in a water bath for $5 \mathrm{~h}$. The second pre-treatment was directed by digesting $30 \mathrm{~g}$ of PPs with $120 \mathrm{ml}$ of $1 \% \mathrm{H}_{3} \mathrm{PO}_{4}$ and the mixture was autoclaved.

During sterilization, the carbohydrates from PPs were degraded into fermentable sugars due to the action of acid hydrolysis $\left(0.5 \mathrm{M} \mathrm{HCl}\right.$ and $\left.1 \% \mathrm{H}_{3} \mathrm{PO}_{4}\right)$ at high temperature of $121^{\circ} \mathrm{C}$ and $1 \mathrm{~atm}$ for $15 \mathrm{~min}$. After sterilization, the $\mathrm{pH}$ was adjusted to 7.0 with $5 \mathrm{M} \mathrm{NaOH}$.

\section{Enzymatic hydrolysis of PPS}

Forty grams of PPs were ground with $59 \mathrm{ml}$ of D.W by a homogenizer, and the mixture was heated in a water bath for $1 \mathrm{~h}$ at $90^{\circ} \mathrm{C}$. The produced substance was treated with either $\alpha$-amylase (Novozymes) or amyloglucosidase (Novozymes) and Sanferm in two steps, namely, dextrinization and saccharification.

- Dextrinization process: One milliliter of $\alpha$-amylase (Novozymes) in a process called liquefaction at $90^{\circ} \mathrm{C}$ and $\mathrm{pH} 5.8$ for $1 \mathrm{~h}$. Samples were taken every $20 \mathrm{~min}$ and subjected to glucose analysis using the 3,5-dinitrosalicylic acid method (Miller, 1959).

- Saccharification process: Achieved by cooling down the mixture to $35-40^{\circ} \mathrm{C}$, then hydrated with water to the original volume. One milliliter of amyloglucosidase
(Novozymes), $54 \mathrm{ml}$ of D.W., and $1 \mathrm{ml}$ of Sanferm yield enzyme (Novozymes) were added to the mixture and treated at $45^{\circ} \mathrm{C}$ and $\mathrm{pH} 4.7$ for $2 \mathrm{~h}$.

\section{Acid hydrolysis of mixed grasses}

Acid hydrolysis of combined grasses was conducted using $3.5 \%$ or $4 \% \mathrm{HCl}$ and $1 \% \mathrm{H}_{2} \mathrm{SO}_{4}$. The $\mathrm{HCl}$ hydrolysis was achieved by mixing $50 \mathrm{~g}$ of fresh grass with $100 \mathrm{ml}$ of D.W., then ground by a homogenizer, $50 \mathrm{ml}$ of either $3.5 \%$ or $4 \%$ of $\mathrm{HCl}$ added, the mixture was autoclaved. $\mathrm{H}_{2} \mathrm{SO}_{4}$ hydrolysis was carried out by adding $0.5 \mathrm{ml}$ of $1 \% \mathrm{H}_{2} \mathrm{SO}_{4}$ to $50 \mathrm{ml}$ of $3.5 \% \mathrm{HCl}$ hydrolysate, then the mixture was autoclaved for $45 \mathrm{~min}$ at $121^{\circ} \mathrm{C}$ and 1 atm.

\section{Ethanol Fermentation of Pretreated Substrates}

Acid hydrolysate $(0.5 \mathrm{M} \mathrm{HCl})$ of PPs

Fermentation was carried out by mixing $40 \mathrm{mg}$ of yeast (Safbrew S-33) with $2 \mathrm{ml}$ of D.W. The mixture incubated at room temperature for $20-25 \mathrm{~min}$ in a $250 \mathrm{ml}$ volume Erlenmeyer flask. Then, $50 \mathrm{ml}$ of acid hydrolysate solution was added to the mixture. The flask was supplemented with tube contains $2 \mathrm{ml}$ of sulfuric acid $\left(\mathrm{H}_{2} \mathrm{SO}_{4}\right)$. Fermentation was continued for 5 days, every $24 \mathrm{~h}$, the mass of the flask was measured to find the amount of ethanol $\mathrm{g} / \mathrm{L}$ production.

\section{Enzymatic hydrolysate of PPS}

Hydrolysate solution of enzymatic hydrolysis of PPs was subjected to ethanol fermentation by $S$. cerevisiae in anaerobic condition at room temperature in a $250 \mathrm{ml}$ Erlenmeyer flask. The inoculum was $60 \mathrm{mg}$ of $S$. cerevisiae, $65 \mathrm{ml}$ of enzyme hydrolysis solution, and $2 \mathrm{ml}$ of $\mathrm{H}_{2} \mathrm{SO}_{4}$. Fermentation was continued for 4 days, every $24 \mathrm{~h}$, the mass of the flask was measured to find the quantity of ethanol $\mathrm{g} / \mathrm{L}$ production.

Acid hydrolysate $(4 \% \mathrm{HCl})$ of mixed grasses

Thirty-five milligrams of $S$. cerevisiae powder were added to $250 \mathrm{ml}$ Erlenmeyer flask that contains $40 \mathrm{ml}$ of $4 \% \mathrm{HCl}$ hydrolysate combined grasses. The $\mathrm{pH}$ adjusted to 7 ; then, the flask was incubated at room temperature supplemented with $2 \mathrm{ml}$ of $\mathrm{H}_{2} \mathrm{SO}_{4}$ Erlenmeyer flask tube, the fermentation was continued for 12 days (Arapoglou, et al., 2010).

\section{E. Biomethanation of Pretreated Substrates}

\section{Acid hydrolysate of PPS}

After the pre-treatment of PPs with $0.5 \mathrm{M} \mathrm{HCl}$, hydrolysate solution was subjected to a batch process methanation at $35^{\circ} \mathrm{C}$ by adding $20 \mathrm{ml}$ of it $\mathrm{pH} 7$ to $500 \mathrm{ml}$ test bottle that previously filled with $300 \mathrm{ml}$ activated sludge.

\section{Enzymatic hydrolysate of PPS}

After the treatment of PPs solution (liquefaction stage) by $\alpha$-amylase and (saccharification stage) by amyloglucosidase and Sanferm. Yield enzyme was subjected to biomethanation process at $35^{\circ} \mathrm{C}$ by adding $20 \mathrm{ml}$ of the final product to a test bottle containing $5.4 \mathrm{ml} \mathrm{S} 4,1 \mathrm{ml} \mathrm{S} 3$, and $300 \mathrm{ml}$ activated sludge.

\section{Acid hydrolysate of mixed grasses}

After the pre-treatment of mixed grass with $4 \% \mathrm{HCl}$, $20 \mathrm{ml}$ of neutralized mixed-grass hydrolysate solution $(\mathrm{pH} 7)$ was mixed with $300 \mathrm{ml}$ of activated sludge in a test bottle to 
perform methanation in a batch process fermentation under mesophilic temperature $35^{\circ} \mathrm{C}$.

\section{Biogas analysis}

In this analysis, biogas production rate measurements were performed using a liquid replacement system (Mahmoodi, et al., 2018). The biogas composition was analyzed using the absorptive method (Mahmoodi, et al., 2018). A scaled cylinder is filled with $0.5 \mathrm{M}$ of $\mathrm{HCl}$ and is reversibly submerged in a container containing the same liquid. A tube connected to a syringe was inserted into the headspace of the test bottle (which contains the activated sludge plus sample), whereas the other end of the tube was placed in the cylinder. At the connection site between the test bottle and the tube, there is a pin, which will be opened when the tube is located at the right spots at both ends. Then, the produced biogas will flow to the cylinder and replace an equal amount of liquid. The volume of the produced gas (Volume 1 in $\mathrm{mL}$ ) was determined by measuring the height space in the cylinder. To measure the methane concentration, $5 \mathrm{~N} \mathrm{NaOH}$ were added to the container to increase the $\mathrm{pH}$ (above 9). At this underlying condition, $\mathrm{CO}_{2}$ and $\mathrm{H}_{2} \mathrm{~S}$ gas are adsorbed, and the volume of the gas is decreased (Volume $2 \mathrm{in} \mathrm{mL}$ ). Therefore, the measured volume represents $\mathrm{CH}_{4}$ content in the biogas mixture. It must be remarked that the variations between the first and the second volume (V1-V2) display the $\mathrm{CO}_{2}$ content of the biogas because $\mathrm{H}_{2} \mathrm{~S}$ concentration is entirely negligible in the adsorbed gas.

\section{Analytical methods}

The dry weight of PPs and fresh mixed grasses was determined by oven drying at $105^{\circ} \mathrm{C}$ for $45 \mathrm{~min}$ to a constant weight. Biochemical methane potential (BMP) was measured (Chynoweth, et al., 1993). The released reducing sugar was measured by a standard method called dinitrosalicylic (Miller, 1959). Quantitative elemental analysis of PPs and mixed grasses for carbon, nitrogen, and hydrogen was measured by the automated Elemental Analyzer EA 3000 Euro Vector in the Central Research Laboratory - UCTM. The chemical oxygen demand (COD) was determined according to the American Public Health Association, 1995. The protein content was defined (Lowry, et al., 1951).

\section{RESUlTS AND Discussion}

\section{A. Characteristic of Substrates}

$P P S$

PPs composition (Table I) contains $16.84 \%$ dry mass weight, $45.5 \%$ carbon, $3.16 \%$ nitrogen, $6.49 \%$ hydrogen, $0.84 \mathrm{mg} / \mathrm{ml}$ reducing sugar, and $10.2 \mathrm{gO}_{2} / \mathrm{L} \mathrm{COD}$. According to this data, PPs can be considered as a wealthy medium containing the most nutrients fundamental for microbial growth (Liang, et al., 2014). Furthermore, the richness of this waste with starch can be used as feedstock for ethanol production. However, the low fermentable reducing sugar content makes the fermentation of the raw material not practical. Therefore, initial hydrolysis (acidic or enzymatic) of carbohydrates is necessary (Pathak, et al., 2018).

\section{Mixed grasses}

A fresh ryegrass (L. perenne) and cocksfoot (D. glomerata) have been identified as a promising feedstock candidate for bio-based alternative energy to create biomethane and ethanol. This is due to its high yield of dry mass weight $20.03 \%$. The analysis of blended grasses was as follows: Carbon $43.63 \%$, nitrogen $2.8 \%$, hydrogen $5.83 \%$, and protein $7 \mathrm{mg} / \mathrm{ml}$ (Table I). Based on these results, grasses can be identified as a promising feedstock candidate for the anaerobic digestion process to produce biogas and ethanol yield by batch procedure fermentation.

\section{B. Pre-treatment of Substrates}

\section{Acid hydrolysis of PPS}

Reducing sugar quantity was increased after acid hydrolysis with $0.5 \mathrm{M} \mathrm{HCl}$, the first and second $1 \% \mathrm{H}_{3} \mathrm{PO}_{4}$ treatment by $31.54,11.47$, and 2.45 folds, respectively (Table II). These findings suggest; first, the rate of hydrolysis boosts by increasing acid concentration which can be a consequence of hydrogen ions activity as a catalyst and second, the digesting of PPs by $1 \% \mathrm{H}_{3} \mathrm{PO}_{4}$ at $100^{\circ} \mathrm{C}$ for $5 \mathrm{~h}$ in water bath produces a higher amount of reducing sugars compared with the autoclave method $\left(121^{\circ} \mathrm{C}\right.$ for $\left.15 \mathrm{~min}\right)$. This is maybe due to the short retention time of the heating solution.

Accordingly, the optimum condition to hydrolyze PPs is utilizing with $0.5 \mathrm{M} \mathrm{HCl}$ at $120^{\circ} \mathrm{C}$ that can liberate high concentration of reducing sugar $(26.5 \mathrm{mg} / \mathrm{ml})$. When comparing our results to those of older studies, it must be pointed out that our method led to better values (Arapoglou, et al., 2010). However, even better results are reported by Sheikh, et al. (2016) when adding $0.5 \% \mathrm{HCl}$ to a dry powder of PPs, then autoclave it at $121^{\circ} \mathrm{C}$, for $15 \mathrm{~min}$.

TABLE I

Chemical Composition of Native Potato Peel and Mixed Grasses

\begin{tabular}{lcc}
\hline \hline Parameters & Potato peels & Mixed grasses \\
\hline Dry mass weight (\%) & 16.84 & 20.03 \\
Nitrogen (\%) & 3.16 & 2.8 \\
Carbon (\%) & 45.5 & 43.63 \\
Hydrogen (\%) & 6.49 & 5.83 \\
Protein content & $7.2 \mathrm{mg} / \mathrm{ml}$ & $7 \mathrm{mg} / \mathrm{ml}$ \\
Reducing sugars & $0.84 \mathrm{mg} / \mathrm{ml}$ & $\mathrm{NA}$ \\
COD & $10.2 \mathrm{gO}_{2} / \mathrm{L}$ & $\mathrm{NA}$ \\
\hline \hline
\end{tabular}

NA*: Not applicable

TABLE II

Chemical Composition of Hydrolysate Potato Peels

\begin{tabular}{lcccc}
\hline \hline Parameters & \multicolumn{4}{c}{ Hydrolysis by } \\
\cline { 2 - 5 } & $0.5 \mathrm{M} \mathrm{HCl}$ & $1^{\text {st }} 1 \% \mathrm{H}_{3} \mathrm{PO}_{4}$ & $2^{\text {nd }} 1 \% \mathrm{H}_{3} \mathrm{PO}_{4}$ & Enzymatic \\
\hline Reducing sugars & $26.5 \mathrm{mg} / \mathrm{ml}$ & $9.64 \mathrm{mg} / \mathrm{ml}$ & $2.06 \mathrm{mg} / \mathrm{ml}$ & $14.98 \mathrm{mg} / \mathrm{ml}$ \\
before fermentation & & & & \\
COD & $35.74 \mathrm{gO} / 1$ & $35.74 \mathrm{gO}_{2} / 1$ & $35.74 \mathrm{gO}_{2} / 1$ & $32.68 \mathrm{gO} / 1$ \\
$\begin{array}{l}\text { Protein content } \\
\text { Reducing sugars }\end{array}$ & $2.8 \mathrm{mg} / \mathrm{ml}$ & $2.94 \mathrm{mg} / \mathrm{ml}$ & $1.2 \mathrm{mg} / \mathrm{ml}$ & $3.49 \mathrm{mg} / \mathrm{ml}$ \\
after fermentation & & $\mathrm{NA}^{*}$ & $\mathrm{NA}^{*}$ & $1.47 \mathrm{mg} / \mathrm{ml}$ \\
BMP & $\mathrm{NA}^{*}$ & $\mathrm{NA}^{*}$ & $\mathrm{NA}^{*}$ & $0.51 \mathrm{CH}_{4} / \mathrm{gCOD}$ \\
\hline \hline
\end{tabular}

NA*: Not applicable, COD: Chemical oxygen demand, BMP: Biochemical methane potential 
Enzymatic hydrolysis of PPS

The degrading ability of the following enzymes to digest PPs carbohydrates and to fermentable reducing sugars was tested; Termamyl $\alpha$-amylase, amyloglucosidase, and Sanferm. The use of Termamyl $\alpha$-amylase was released $12.45 \mathrm{mg} / \mathrm{ml}$ of reducing sugar that has been used as a substrate for amyloglucosidase plus Sanferm yield enzymes, which, in turn, released $14.98 \mathrm{mg} / \mathrm{ml}$ of reducing sugar (Table II). These outcomes demonstrate that the saccharification stage alone is an insufficient step for bioethanol production. However, when carbohydrates complex converted into simple monomers, a better production was obtained. Hence, a preparatory dextrinization stage was required. For this reason, the utility of enzyme combination was necessary for compelling hydrolysis of PPs. These results confirm previous findings by Khawla, et al., 2014; Izmirlioglu and Demirci, 2012; and Sujeeta, et al., 2018.

Overall, our results confirmed that acid hydrolysis by $0.5 \mathrm{M} \mathrm{HCl}$ separates $26.5 \mathrm{mg} / \mathrm{ml}$ of fermentable reducing sugar and it has higher $35.74 \mathrm{gO}_{2} / \mathrm{L}$ COD compared to enzymatic hydrolysis, which were $14.98 \mathrm{mg} / \mathrm{ml}$ of reducing sugar and $32.68 \mathrm{gO}_{2} / \mathrm{L}$ of COD. These variations of production may due to the way of acid treatment that was carried out under a higher temperature of $120^{\circ} \mathrm{C}$ and utilizing mild acid concentration. However, enzymatic treatment leads to complete hydrolysis of the starch component and is highly substrate specific (de Souza, et al., 2019).

These results showed that both strategies were successfully recovered reducing sugar from PPs. Financially acid hydrolysis was more beneficial that requires severe conditions such as high temperature $\left(120^{\circ} \mathrm{C}\right)$ and low $\mathrm{pH}$ (4). However, such conditions support the use of expensive corrosiveresistant equipment. Furthermore, they are restricted by the requirements of a neutralization step before fermentation and the generation of inhibitory by-products such as furfural and 5-hydroxymethylfurfural. Hence, enzymatic hydrolysis is more beneficial due to its low toxicity and low corrosion; no inhibitory is formed and requires less energy and mild environmental conditions (Maurya, et al., 2015).

\section{Acid hydrolysis of mixed grasses}

Acid pretreatment is likely to be the preferred choice for fresh grass because of the progressed degradation of xylan, which is the crucial component of hemicellulose. The quantity of reducing sugar increased 2-fold using $4 \% \mathrm{HCl}$, if we compare it with $3.5 \% \mathrm{HCl}$ pre-treatment (Table III) which drive us to conclude that the production of glucose can be increased through increasing the concentration of treated acid. A slight increase in reducing sugar production was observed by adding $1 \% \mathrm{H}_{2} \mathrm{SO}_{4}$ to hydrolysate solution of $3.5 \% \mathrm{HCl}$. Our results are broadly in line with other studies (Tanangteerapong, et al., 2017; Valva and Tichagwa, 2013).

\section{Bioethanol Production from PPs and Mixed Grasses through Anaerobic Fermentation}

\section{Acid hydrolysate of PPS}

Acidic hydrolysis produced $26.5 \mathrm{mg} / \mathrm{ml}$ reducing sugar. The produced sugar had been subjected to fermentation by
TABLE III

Characteristic of Acid Hydrolysate of Combined Grasses Lolium PERENNE AND DACTYLIS GLOMERATA SPECIES

\begin{tabular}{lccc}
\hline \hline Parameters & \multicolumn{3}{c}{ Hydrolysis by } \\
\cline { 2 - 4 } & $3.5 \% \mathrm{HCl}$ & $4 \% \mathrm{HCl}$ & $1 \% \mathrm{H}_{4} \mathrm{SO}_{4}$ \\
\hline Reducing sugars & $14.98 \mathrm{mg} / \mathrm{ml}$ & $28.8 \mathrm{mg} / \mathrm{ml}$ & $16.92 \mathrm{mg} / \mathrm{ml}$ \\
Protein content & $7 \mathrm{mg} / \mathrm{ml}$ & $6.5 \mathrm{mg} / \mathrm{ml}$ & $6.1 \mathrm{mg} / \mathrm{ml}$ \\
COD & $45.8 \mathrm{gO}_{2} / 1$ & $45.8 \mathrm{gO}_{2} / 1$ & $45.8 \mathrm{gO}_{2} / 1$ \\
BMP & $0.541 \mathrm{CH}_{4} / \mathrm{gCOD}$ & $0.541 \mathrm{CH}_{4} / \mathrm{gCOD}$ & $0.541 \mathrm{CH}_{4} / \mathrm{gCOD}$ \\
\hline \hline
\end{tabular}

COD: Chemical oxygen demand, BMP: Biochemical methane potential

Safbrew $S$-33, and $1.69 \mathrm{mg} / \mathrm{ml}$ of reducing sugar remained and fermentable reducing sugars were $24.81 \mathrm{mg} / \mathrm{ml}$. These results indicate that the yeast efficiently utilized most of the reducing sugar as a nutrient source for fermentation. Fig. 1 shows the investment of ethanol generation $(\mathrm{g} / \mathrm{L})$ during PPs hydrolysate fermentation. The maximum ethanol produced was $0.4311 \mathrm{~g} / \mathrm{L}$ after $98 \mathrm{~h}$ fermentation, along these lines leveling off to $98 \mathrm{~h}$ with a slight diminish from that point. When comparing our results to the previous studies, it shows lower values than those of Arapoglou, et al., 2010 and Hashem and Darwish, 2010.

The low yields of ethanol are likely due to the presence of microorganism inhibitors such as furfural and 5-hydroxymethylfurfurals within the hydrolysate. This is causing slow xylose and hexose consumption during fermentation. Furthermore, Safbrew lacks the mechanism to take up pentose sugars as a substrate in acid hydrolysate, which probably contains a high amount of five-carbon sugar (Robak and Balcerek, 2018).

\section{Enzymatic hydrolysate of PPS}

The quantity of reducing sugar after enzymatic hydrolysis of PPs was $14.98 \mathrm{mg} / \mathrm{ml}$. The combination of enzymatic hydrolysates solution was directed to fermentation to assess the ethanol generation. After fermentation, the total amount of reducing sugars was $1.47 \mathrm{mg} / \mathrm{ml}$. From the results, it is clear that $S$. cerevisiae produced high quantities of ethanol on PPs (Fig. 1) that were previously treated with $\alpha$-amylase, amyloglucosidase, and Sanferm. The highest quantity of ethanol production was achieved after $42 \mathrm{~h}$ of fermentation $(1.2 \mathrm{~g} / \mathrm{L})$.

Results indicate that $19.6 \mathrm{~g} / \mathrm{L}$ of ethanol was produced after $33 \mathrm{~h}$ of fermentation using a combination of Termamyl $\alpha$-amylase and amyloglucosidase (Khawla, et al., 2014). Higher quantity of ethanol was obtained, which was $30.99 \mathrm{~g} / \mathrm{L}$ after $48 \mathrm{~h}$ of fermentation through enzymatic hydrolysis using a combination of $1 \mathrm{ml} \alpha$-amylase at $95^{\circ} \mathrm{C}$ for $3 \mathrm{~h}$ and $0.2 \mathrm{ml}$ amyloglucosidase at $30^{\circ} \mathrm{C}$ for $48 \mathrm{~h}$ (Izmirlioglu and Demirci, 2012).

This result shows that enzymatic hydrolysis leads to high yield of ethanol generation compared to acidic hydrolysate. It reveals that utilizing $S$. cerevisiae can efficiently ferment both pentose and hexose sugars more than Safbrew yeast. The capacity of every microorganism to ferment of reducing sugars, which includes glucose, xylose, arabinose, galactose, and mannose, after hydrolysis of cellulose and hemicellulose are different (Yang, et al., 2014). Our finding on ethanol 


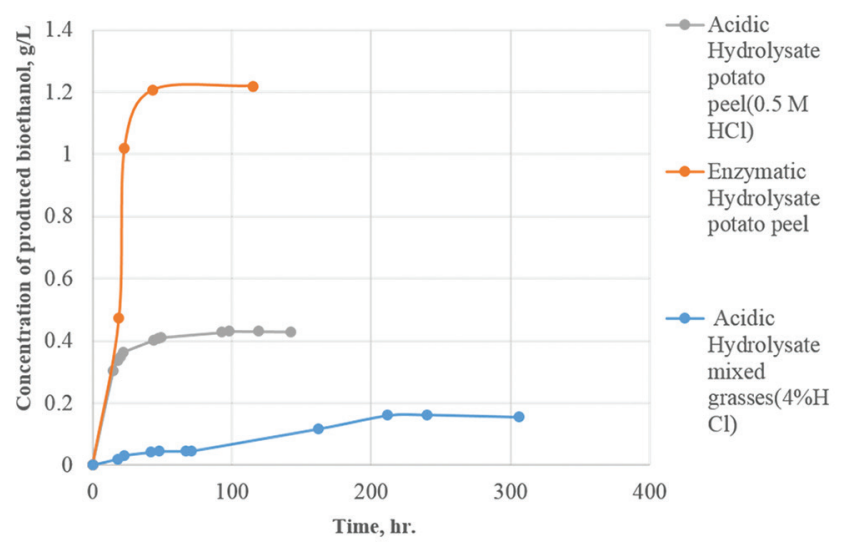

Fig. 1. Kinetics of bioethanol production from hydrolysate potato peels and combined grasses.

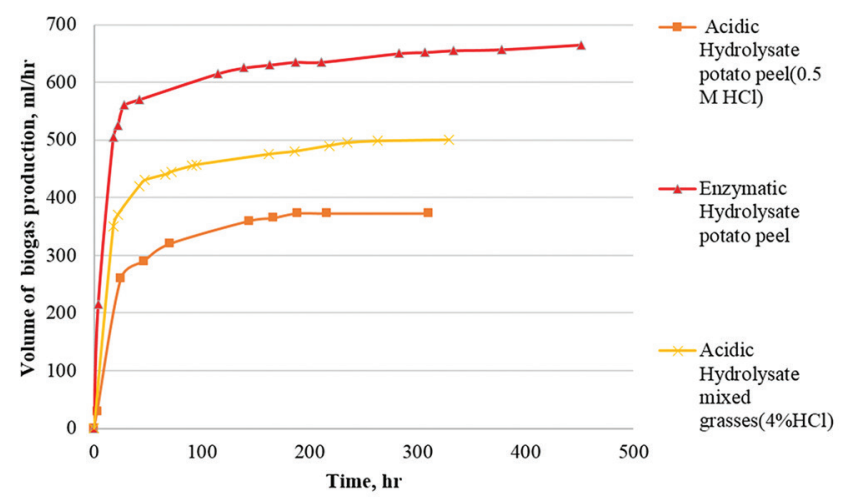

Fig. 2. Batch processes of biogas production from native and pretreated potato peels and mixed grasses.

generation at least provides some critical parameters for ethanol production from PPs which were the enzyme combination, the dose and the residence time of hydrolysis. A high yield of ethanol was obtained after liquefaction, saccharification, and fermentation by $S$. cerevisiae. The method of producing ethanol in this work is promising and shows that PPs of the potato industry treated with a locally produced enzyme, features an appealing feedstock for the bioethanol production. Moreover, bioconversion gives a reasonably priced and secure approach to produce cheap, clean energy and decreases the environmental pollutants caused by PPs.

\section{Acid hydrolysate of mixed grasses}

The quantity of reducing sugar was decreased 14.76-fold (from $28.8 \mathrm{mg} / \mathrm{ml}$ to $1.95 \mathrm{mg} / \mathrm{ml}$ ) after fermentation in the presence of $S$. cerevisiae. This suggests that the yeast to grow utilized almost all of the reduced sugar $(26.85 \mathrm{mg} / \mathrm{ml})$. In contrast, the production of ethanol was elevated over 8 days of fermentation from $0.05 \mathrm{~g} / \mathrm{L}$ to $0.16 \mathrm{~g} / \mathrm{L}$ (Fig. 1). A similar pattern of results with higher values was obtained by Eliana, et al., 2014.

The low level of ethanol production can be returned to many factors, the first is the end product of acid pre-treatment such as acetic acid, furfural, and 5-hydroxymethylfurfural which are yeast growth inhibitors. This problem can be solved through neutralization and then detoxification of hydrolysates. The second factor can be a result of the inability of $S$. cerevisiae to utilize 5-carbon sugars that include in the mixed grass (Tesfaw and Assefa, 2014).

\section{Biogas Production from PPs and Mixed Grasses through Batch Process Methanation}

Acid hydrolysate $(0.5 \mathrm{M} \mathrm{HCl})$ of PPs

After pre-treatment of PPs with $0.5 \mathrm{M} \mathrm{HCl}$, hydrolysate solution was subjected to a batch process methanation under mesophilic condition $35^{\circ} \mathrm{C}$. A rapid degradation rate of organic matter, protein, and carbohydrate with considerable biogas $(260 \mathrm{ml} / \mathrm{h})$ was obtained from the $1^{\text {st }}$ day of batch process methanation (Fig. 2). These results suggest a methanogenic phase highly active from the $1^{\text {st }}$ day of anaerobic digestion. After few days, the rate of biogas production steadily increased. The highest average volume of biogas was $373 \mathrm{ml} / \mathrm{h}$ after $188 \mathrm{~h}$ of methanation process, after that remained constant. This maximum yield of biogas production shows that the highest intake of organic matter was observed on the last day of the methanation process. In comparison with the enzymatic hydrolysate of PPs, low yield of biogas production was obtained from $0.5 \mathrm{M} \mathrm{HCl}$ treatment of PPs. The reason can be returned to lack of supplementary microelement, formation of bacterial inhibitor, and production of toxic compounds which, in turn, suppress bacterial growth.

\section{Enzymatic hydrolysate of PPS}

The resulted PPs solution from liquefaction and saccharification stages was subjected to biomethanation process at $35^{\circ} \mathrm{C}$. The fast degradation rate and intake of organic matter were seen over $24 \mathrm{~h}$ of methanation process (Fig. 2) with a considerable amount of biogas investment $215 \mathrm{ml} / \mathrm{h}$, which increased more than 2-fold after $48 \mathrm{~h}$ $(570 \mathrm{ml} / \mathrm{h})$ of the process.

These results demonstrate two facts; first, the methanogenic phase activates from the $2^{\text {nd }}$ day of anaerobic digestion. Second, the highest quantity of biogas can be acquired after $451 \mathrm{~h}$ of methanation process.

Enzymatic hydrolysate of PPs gives higher quantity (2-fold) of biogas production compared to acid hydrolysate, this can be returned to the ability of used enzymes to degrade PPs and make it amenable to bacterial methanogenic fermentation. It is worth mentioning that the presence of microelements in the hydrolysis process has positive effect on enhancing the rate of biogas production, and no inhibitory by-product is formed in enzymatic hydrolysis.

Depending on the obtained data, enzymatic hydrolysis has several benefits compared to acidic hydrolysis. They include works beneath moderate conditions, are biodegradable, enhance yields, decrease energy, water utilization, and the amount of by-products like furfural.

\section{Acid hydrolysate $(4 \% \mathrm{HCl})$ of mixed grasses}

The results of methanization of mixed grasses hydrolysate $(4 \% \mathrm{HCl})$ of perennial ryegrass (L. perenne) and cocksfoot (D. glomerata) indicate that the rapid degradation rate of organic matter content was noticed from the $1^{\text {st }}$ day (Fig. 2) 
TABLE IV

Measurement of Biogas Composition

\begin{tabular}{lccc}
\hline \hline Substrates & $\%$ biogas & $\% \mathrm{CO}_{2}$ & $\% \mathrm{CH}_{4}$ \\
\hline $0.5 \mathrm{M} \mathrm{HCl}$ hydrolysis (PPs) & 37.3 & 4 & 33.3 \\
Enzymatic hydrolysate (PPs) & 66.5 & 2 & 64.5 \\
$4 \% \mathrm{HCl}$ hydrolysis (mixed grass) & 50 & 2 & 48 \\
\hline \hline
\end{tabular}

PPs: Potato peels

with a significant quantity of biogas production $(350 \mathrm{ml} / \mathrm{h})$. Biogas yields were raised from the $2^{\text {nd }}$ day to the $9^{\text {th }}$ day of batch process methanation. The highest volume over the $13^{\text {th }}$ day of batch process methanation was $500 \mathrm{ml} / \mathrm{h}$. This is consistent with what has been found in the previous studies by Mahnert, et al., 2005 and Ngumah, et al., 2013.

This high yield of biogas may be due to $4 \% \mathrm{HCl}$ pre-treatment of lignocellulosic combined grasses, and it could hydrolyze most of the hemicellulose into its element sugars. The following values were determined after acid hydrolysis of combined grasses; reducing sugar $(28.8 \mathrm{mg} / \mathrm{ml})$, protein content $(6.5 \mathrm{mg} / \mathrm{ml})$, COD $\left(45.8 \mathrm{gO}_{2} / \mathrm{L}\right)$, and $\mathrm{BMP}$ $\left(0.541 \mathrm{CH}_{4} / \mathrm{gCOD}\right)$. These results confirm that pre-treatment strategies of grasses for biogas manufacturing enhance and boost up the degradation process attaining high biogas yields.

\section{Biogas composition}

The two main components of biogas are $\mathrm{CH}_{4}$ and $\mathrm{CO}_{2}$, also can include small quantities of nitrogen, hydrogen, hydrogen sulfide, and water vapor (Mahmoodi, et al., 2018).

The ratio of biogas content was produced by the anaerobic digestion process from PPs and combined grasses substrate (Table IV). Methane production was determined after the biogas passed through a cylinder containing $5 \mathrm{~N} \mathrm{NaOH}$ solution to increase the $\mathrm{pH}$. This alkaline solution adsorbs $\mathrm{CO}_{2}$ and other gas from the biogas mixture, and the gas volume is decreased. Therefore, the measured volume represents $\mathrm{CH}_{4}$ content in the biogas mixture. It was noted that the variation between the biogas and methane volume displays the $\mathrm{CO}_{2}$ content of the biogas because $\mathrm{H}_{2} \mathrm{~S}$ concentration is entirely negligible in the adsorbed gas. Determination of biogas composition needs to perform to qualify biogas as natural gas which environmentally friendly and safe for health.

\section{CONCLUSION}

The main conclusion that can be drawn from this work is that PPs and mixed grasses are valuable substrates for biomethanation, which can be applied in small and big scales.

Importantly, our results proved on the one hand that the enzymatic treatment of PPs produces ethanol and biogas after fermentation much more than the acidic treatment, which was $1.2 \mathrm{~g} / \mathrm{L}$ ethanol after $42 \mathrm{~h}$ of fermentation and $665 \mathrm{ml} / \mathrm{h}$ biogas over $451 \mathrm{~h}$ of batch process methanation. On the other hand, this work argued that $4 \% \mathrm{HCl}$ is the best way to hydrolyze blended grass, which released $28.8 \mathrm{mg} /$ $\mathrm{ml}$ of reduced sugar, produced $0.16 \mathrm{~g} / \mathrm{L}$ ethanol over 8 days of fermentation and $500 \mathrm{ml} / \mathrm{h}$ of biogas after the $13^{\text {th }}$ day of batch process methanation.

\section{ACKNOWLEDGMENT}

This research was supported by Erasmus Mundus Marhaba Program. Thanks are due to the Faculty of Chemical System Engineering, Department of Biotechnology, University of Chemical Technology and Metallurgy in Sofia and Bulgaria, where the project was performed. Thanks extend to the Department of Medical Microbiology, Faculty of Science and Health, Koya University.

\section{REFERENCES}

American Public Health Association. 1995. Standard Methods for the Examination of Water and Wastewater. American Public Health Association, Washington, DC.

Arapoglou, D., Varzakas, T., Vlyssides, A. and Israilides, C. 2010. Ethanol production from potato peel waste (PPW). Waste Management, 30, pp.1898-1902.

Aziz, N.I.H., Hanafiah, M.M. and Gheewala, S.H. 2019. A review on life cycle assessment of biogas production: Challenges and future perspectives in Malaysia. Biomass and Bioenergy, 122, pp.361-374.

Chynoweth, D., Turick, C., Owens, J., Jerger, D. and Peck, M. 1993. Biochemical methane potential of biomass and waste feedstocks. Biomass and Bioenergy, 5, pp.95-111.

de Souza, I.A., Orsi, D.C., Gomes, A.J. and Lunardi, C.N. 2019. Enzymatic hydrolysis of starch into sugars is influenced by microgel assembly. Biotechnology Reports, 22, p.e00342.

Eliana, C., Jorge, R., Juan, P. and Luis, R. 2014. Effects of the pretreatment method on enzymatic hydrolysis and ethanol fermentability of the cellulosic fraction from elephant grass. Fuel, 118, pp.41-47.

Hashem, M. and Darwish, S.M. 2010. Production of bioethanol and associated by-products from potato starch residue stream by Saccharomyces cerevisiae. Biomass and Bioenergy, 34(7), pp.953-959.

Izmirlioglu, G. and Demirci, A. 2012. Ethanol production from waste potato mash by using Saccharomyces cerevisiae. Applied Sciences, 2, pp.738-753.

Khawla, B.J., Sameh, M., Imen, G., Donyes, F., Dhouha, G., Raoudha, E.G. and Oumèma, N.E. 2014. Potato peel as feedstock for bioethanol production: A comparison of acidic and enzymatic hydrolysis. Industrial Crops and Products, 52, pp.144-149.

Li, L., Kong, X., Yang, F., Li, D., Yuan, Z. and Sun, Y. 2012. Biogas production potential and kinetics of microwave and conventional thermal pretreatment of grass. Applied Biochemistry and Biotechnology, 166, pp.1183-1191.

Liang, S. and Mcdonald, A.G. 2014. Chemical and thermal characterization of potato peel waste and its fermentation residue as potential resources for biofuel and bioproducts production. Journal of Agricultural and Food Chemistry, 62, pp.8421-8429.

Liang, S., Mcdonald, A.G. and Coats, E.R. 2014. Lactic acid production with undefined mixed culture fermentation of potato peel waste. Waste Management, 34, pp.2022-2027.

Lowry, O.H., Rosebrough, N.J., Farr, A.L. and Randall, R.J. 1951. Protein measurement with the Folin phenol reagent. Journal of Biological Chemistry, 193, pp.265-275.

Mahmoodi, P., Farmanbordar, S. and Karimi, K. 2018. Analytical Methods in Biogas Production. Springer, Cham, Switzerland, pp.221-238.

Mahnert, P., Heiermann, M. and Linke, B. 2005. Batch-and semi-continuous biogas production from different grass species. Agricultural Engineering International: CIGR Journal, 7, pp.5-10.

Maurya, D.P., Singla, A. and Negi, S. 2015. An overview of key pretreatment processes for biological conversion of lignocellulosic biomass to bioethanol. 3 Biotech, 5, pp.597-609. 
Miller, G.L. 1959. Use of dinitrosalicylic acid reagent for determination of reducing sugar. Analytical Chemistry, 31, pp.426-428

Mulat, D.G., Dibdiakova, J. and Horn, S.J. 2018. Microbial biogas production from hydrolysis lignin: Insight into lignin structural changes. Biotechnology for Biofuels, 11, p.61.

Ngumah, C., Ogbulie, J., Orji, J. and Amadi, E. 2013. Biomethanation of carpet grass (Axonopus fissifolius). Environmental Research, Engineering and Management, 66(4), pp.34-37.

Pathak, P.D., Mandavgane, S.A., Puranik, N.M., Jambhulkar, S.J. and Kulkarni, B.D. 2018. Valorization of potato peel: A biorefinery approach. Critical Reviews in Biotechnology, 38, pp.218-230.

Phuttaro, C., Sawatdeenarunat, C., Surendra, K., Boonsawang, P., Chaiprapat, S. and Khanal, S.K. 2019. Anaerobic digestion of hydrothermally-pretreated lignocellulosic biomass: Influence of pretreatment temperatures, inhibitors and soluble organics on methane yield. Bioresource Technology, 284, pp.128-138.

Robak, K. and Balcerek, M. 2018. Review of second generation bioethanol production from residual biomass. Food Technology and Biotechnology, 56(2), p.174.

Rodriguez, C., Alaswad, A., Benyounis, K. and Olabi, A.G. 2017. Pretreatment techniques used in biogas production from grass. Renewable and Sustainable Energy Reviews, 68, pp.1193-1204.

Sanchez, O. and Cardona, C. 2008. Trends in biotechnological production of fuel ethanol from different feedstocks. Bioresource Technology, 99, pp.5270-5295.

Sheikh, R.A., Al-Bar, O.A. and Soliman, Y.M.A. 2016. Biochemical studies on the production of biofuel (bioethanol) from potato peels wastes by Saccharomyces cerevisiae: Effects of fermentation periods and nitrogen source concentration.
Biotechnology and Biotechnological Equipment, 30(3), pp.497-505.

Sujeeta, K.M., Mehta, S. and Sihag, K. 2018. Optimization of conditions for bioethanol production from potato peel waste. International Journal Chemical Studies, 6(1), pp.2021-2024.

Tanangteerapong, D., Tunjaroensin, T., Trakun-Ung, P. and Kamwilaisak, K. 2017. Production of reducing sugars from hydrolysis of napier grass by acid or alkali. Chiang Mai University Journal of Natural Sciences, 16(1), p.32.

Tesfaw, A. and Assefa, F. 2014. Current trends in bioethanol production by Saccharomyces cerevisiae: substrate, inhibitor reduction, growth variables, coculture, and immobilization. International Scholarly Research Notices, 2014, 2014, p. 532852 .

Thangavelu, S.K., Ahmed, A.S. and Ani, F.N. 2016. Review on bioethanol as alternative fuel for spark ignition engines. Renewable and Sustainable Energy Reviews, 56, pp.820-835.

Tran, T.T.A., Le, T.K.P., Mai, T.P. and Nguyen, D.Q. 2019. Bioethanol production from lignocellulosic biomass. In: Alcohol Fuels-Current Technologies and Future Prospect. IntechOpen, London.

Valva, R.M. and Tichagwa, L. 2013. Low temperature acid hydrolysis of grassderived lignocellulose for fermentable sugars production. Cellulose Chemistry and Technology, 47(7-8), pp.565-572.

Wagner, A., Lackner, N., Mutschlechner, M., Prem, E., Markt, R. and Illmer, P. 2018. Biological pretreatment strategies for second-generation lignocellulosic resources to enhance biogas production. Energies, 11, p.1797.

Yang, T.C., Kumaran, J., Amartey, S., Maki, M., Li, X., Lu, F. and Qin, W. 2014. Biofuels and bioproducts produced through microbial conversion of biomass. Bioenergy Research: Advances and Applications, 2014, pp.71-93. 